\title{
Nekultivacijske metode u dijagnostici invazivne kandidijaze
}

\author{
"Non-culture" methods in diagnostics of invasive candidiasis \\ Dea Ratković, Maja Abram ${ }^{2,3}$, Marina Bubonja-Šonje ${ }^{2,3}$ \\ 1 Služba za mikrobiologiju, Nastavni zavod za javno zdravstvo Istarske županije, Pula, Hrvatska \\ ${ }^{2}$ Zavod za mikrobiologiju i parazitologiju, Medicinski fakultet, Sveučilište u Rijeci, Rijeka, Hrvatska \\ ${ }^{3}$ Klinički zavod za kliničku mikrobiologiju, Klinički bolnički centar Rijeka, Rijeka, Hrvatska
}

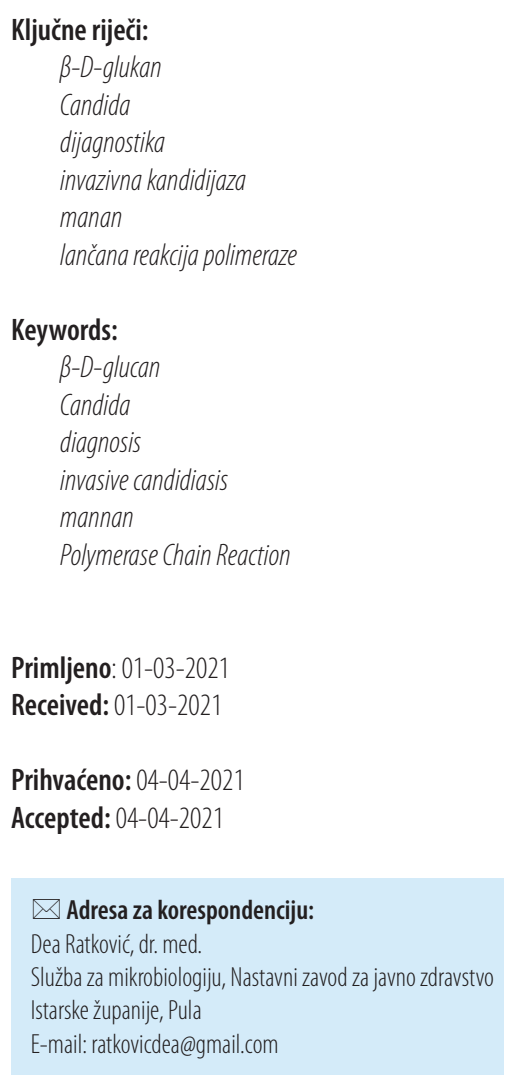

\begin{abstract}
Sažetak
Invazivne gljivične infekcije uzrokovane vrstama iz roda Candida česte su u kritično oboljelih bolesnika i povezane su sa značajnim morbiditetom i mortalitetom. Pravovremeno postavljanje dijagnoze je od presudnog značaja budući da svako odgađanje primjene antifungalnih lijekova utječe na ishod liječenja. Zbog ograničenja klasičnih dijagnostičkih metoda zasnovanih na kultivaciji - njihove sporosti i nedovoljne osjetljivosti, nekultivacijske imunološke i molekularne dijagnostičke metode sve više nalaze svoje mjesto u dijagnostici invazivne kandidijaze. Nekultivacijske metode, kao što je određivanje biomarkera ili lančana reakcija polimeraze (engl. Polymerase Chain Reaction, P(R) imaju veliki dijagnostički potencijal. Primjerice, negativan rezultat PCR testa ili 1,3- $\beta$-D-glukana (BDG) ima visoku negativnu prediktivnu vrijednost (NPV) tj. veliku vjerojatnost odsustva bolesti. U svrhu povećanja pouzdanosti pojedine metode preporučuje se kombiniranje različitih metoda kao i tumačenje dobivenih rezultata u skladu s kliničkim, epidemiološkim, laboratorijskim i drugim podatcima.
\end{abstract}

\begin{abstract}
Summary
Invasive fungal infections, especially those caused by Candida species, are not uncommon in critically ill patients and are associated with significant morbidity and mortality. Early diagnosis is essential because delaying the use of antifungal drugs can affect treatment outcome. Due to the limitations of classical culture-based methods (they are time-consuming and insensitive), trends in diagnostics switch to "non-culture" based methods for early diagnosis of invasive candidiasis. „Non-culture" methods, such as biomarker detection or Polymerase Chain Reaction (PCR) techniques, have great diagnostic potential. For example, a negative PCR or 1,3-B-D-glucan (BDG) test result have a high negative predictive value (NPV). In order to increase the reliability of each method, it is recommended to combine different methods as well as to interpret the obtained results in accordance with the clinical, epidemiological, laboratory and other patient data.
\end{abstract}

\section{Uvod}

Izraz „invazivna gljivična infekcija“ koristi se za opis ozbiljne, sustavne infekcije uzrokovane kvascima ili plijesnima ${ }^{[1]}$. Invazivne gljivične infekcije su rastući problem suvremene medicine zbog sve većeg broja imunokompromitiranih bolesnika. Prema podacima američkog Centra za kontrolu i sprječavanje bolesti (engl. Centers for Disease Control and Prevention, CDC) u periodu od 2013. do 2017. god. infekcije kvascima roda Candida bile su odgovorne za 8-10 \% pozitivnih hemokultura, dok je u Europi taj postotak nešto niži te iznosi oko 2-3 \% ${ }^{[2,3]}$.

Kandida čini dio normalne mikrobiote kože, sluznica i probavnog sustava čovjeka ne uzrokujući pri tom simptome bolesti, međutim, pod određenim uvjetima može doći do lokalnog umnožavanja stanica kvasca, invazije i prodora u krvotok te daljnje diseminacije po organizmu. Za razliku od lokalizirane, često samo-ograničavajuće površinske infekcije kao što je oralna ili vaginalna kadidijaza, invazivna kandidijaza predstavlja generaliziranu, sustavnu infekciju koja zahvaća krv i/ili različite duboke organe kao što su srce, mozak, oči, kosti itd. ${ }^{[1]}$. Glavni činitelji rizika su: neutropenija nakon kemoterapije ili imunosupresivnog liječenja (onkološki, hematološki i transplantirani bolesnici), primjena antibiotske terapije širokog spektra, prisutnost središnjeg venskog katetera, urinarnog katetera, parenteralna prehrana, bubrežna 
dijaliza, ugradnja endoproteza itd. Do prodora kandide u krv - primarne kandidemije, najčešće dolazi ili nakon translokacije kandide iz crijeva ili s kontaminiranog/koloniziranog intravenskog ili peritonealnog katetera. Istraživanja pokazuju da oko $50 \%$ primarnih kandidemija zbog hematogenog rasapa ima za posljedicu sekundarnu kandidijazu dubokih tkiva ili organa. Invazivna kandidijaza se stoga može podijeliti u (i) kandidemiju bez zahvaćanja unutarnjih organa, (ii) kandidemiju s diseminacijom u unutarnje organe i (iii) kandidijazu različitih unutarnjih organa u odsutnosti kandidemije (hemokulture negativne) ${ }^{[4]}$.

Do danas je identificirano preko 30 različitih pripadnika roda Candida koji mogu uzrokovati infekcije u ljudi. Ipak, većinu infekcija uzrokuju vrste C. albicans, C. glabrata, C. tropicalis, C. parapsilosis i C. kru$s e i^{[5]}$. Iako je C. albicans godinama bila vodeći uzročnik invazivne kandidijaze, posljednjih godina pod utjecajem antifungalne terapije dolazi do selekcije rezistentnijih vrsta te su non-albicans vrste sada odgovorne za gotovo polovinu invazivnih gljivičnih infekcija. Retrospektivnom je analizom utvrđeno da je u Sjedinjenim Američkim Državama C. albicans uzrokovala $48 \%$ invazivnih kandidijaza u razdoblju od 2009. do 2017. god. ${ }^{[6]}$. Sljedeća najčešća vrsta bila je C. glabrata koja je imala veću stopu smrtnosti od C. albicans i češće uzrokovala invazivnu kandidijazu kod bolesnika starijih od 65 god. C. parapsilosis je imala nižu stopu smrtnosti od drugih vrsta iz roda Candida, a češće je uzrokovala kandidijazu u novorođenčadi.

Upravo je raširenost uporabe flukonazola potaknula pojavu vrsta rezistentnih na azole. Za razliku od $C$. albicans, non-albicans vrste pokazuju smanjenu osjetlivost prema antifungalnim lijekovima iz skupine azola i/ ili ehinokandina zbog čega je presudna pravodobna dijagnostika i brza primjena djelotvornog lijeka. Nedavna pojava novih, višestruko otpornih vrsta, poput $C$. auris još više naglašava važnost pravovremene dijagnostike i liječenja koji, nažalost, nisu uvijek niti jednostavni, niti mogući.

\section{Klasična dijagnostika}

Klasična dijagnostika gljivične infekcije zasniva se prvenstveno na fenotipskim metodama poput izravnog mikroskopskog ispitivanja kliničkih uzoraka, histopatoloških tehnika i izolacije gljiva iz uzorka (mikološka kultura). Takav dijagnostički pristup zahtijeva educirano stručno osoblje s relativno visokom razinom specifičnog mikološkog obrazovanja što je ograničavalo dijagnostiku na specijalizirane mikološke laboratorije. Mikroskopskim i citološkim tehnikama mogu se otkriti dijelovi gljivičnih elemenata u bolesničkim uzorcima. Izravna mikroskopska pretraga je brza i učinko- vita metoda koja daje vrlo korisnu informaciju ako je rezultat pozitivan. Izravna se vizualizacija gljivičnih struktura u kliničkim uzorcima olakšava korištenjem $10 \%$ kalij-hidroksida $(\mathrm{KOH})$ te primjenom različitih tehnika bojenja, kao što su bojenje po Gramu, Giemsi ili bojenje metenamin-srebrom po Gomoriju. Primjena fluorescentnih boja kao što je akridin narančasta, koja boji nukleinske kiseline ili kalkofluor bijele boje, koja boji hitin u staničnoj stijenci gljiva, povećava osjetljivost mikroskopije budući da omogućuje otkrivanje manjeg broja gljivičnih stanica $\left(1 \times 10^{4}\right.$ stanica/ $\mathrm{ml})$. Iako brze, ove metode nisu dovoljno osjetljive te negativan rezultat mikroskopskog nalaza ne isključuje gljivičnu infekciju. Postupak kultivacije ima nešto veću osjetljivost u odnosu na mikroskopiju, ali je vremenski zahtijevan. Premda se kultivacijom može dokazati svega 40-60 \% invazivnih infekcija uzrokovanih kandidom, ova se klasična metoda još uvijek smatra zlatnim standardom u dijagnostici invazivne kandidijaze ${ }^{[7]}$. Uz sporost i nisku osjetljivost kultivacije dodatnu poteškoću predstavlja činjenica da je za kultivaciju ponekad potrebno uzeti invazivan klinički uzorak kao što su bronhoalveolarni lavat (BAL) ili bioptat što može predstavljati veliki rizik za bolesnike koji su često u kritičnom stanju, imaju trombocitopeniju, sklonost krvarenju itd. Za uzgoj kvasaca najčešće se upotrebljava Sabouraudov glukozni agar uz dodatak antibiotika, a primjena komercijalnih kromogenih hranjivih podloga, kao što je HiCrome ${ }^{\mathrm{Tm}}$ Candida Differential Agar (HiMedia, India), skraćuje i olakšava postupak identifikacije. Prema preporukama ESCMID/EFISG (engl. European Society for Clinical Microbiology and Infectious Diseases / European Fungal Infection Study Group) krv bolesnika sa suspektnom kandidemijom treba kultivirati u aerobnim i anaerobnim medijima za hemokulturu, kao što je BACTEC 9240 (Becton Dickinson, USA). Međutim, dodatak selektivnog medija za gljive (npr. BACTEC ${ }^{\text {rm }}$ Mycosis-IC/F, Becton Dickinson, USA) standardnom setu aerobnih i anaerobnih medija za hemokulturu ubrzava detekciju nekih vrsta kandida. Nawrot i sur. su pokazali da je detekcija C. glabrata iz krvi znatno brža ako se uz standardna bakterijska hranilišta za hemokulturu koriste i selektivna hranilišta za gljive ${ }^{[8]}$. Standardna hemokultura ima osjetljivost oko $50 \%$ u otkrivanju kandidemije, a kod bolesnika $s$ diseminiranom kandidijazom visceralnih organa hemokulture mogu biti i negativne. Razlog tako niskoj osjetljivosti hemokulture leži u činjenici da je u vrijeme prve epizode kandidemije broj cirkulirajućih gljivičnih stanica obično manji od 1 $\mathrm{CFU} / \mathrm{mL}$ (engl. colony forming units) ${ }^{[9]}$. Stoga je zbog povećanja osjetljivosti pretrage istu potrebno ponavljati (jedanput dnevno u febrilnog bolesnika, odnosno jednom tjedno u ostalih), uzimati veći volumen krvi 
(>40-60 ml/dnevno) koristiti specijalizirane bočice sa selektivnim medijem za gljive te uzimati uzorke krvi prije početka antifungalne terapije. Dodatnu poteškoću u kultivaciji kandide iz krvi predstavlja vrijeme koje je potrebno da automatizirani inkubator u kojem se bočice kultiviraju signalizira porast. Naime, za to je obično potrebno nekoliko dana, nakon čega je potrebno hemokulturu presaditi na kruta hranilišta radi identifikacije i određivanja osjetljivosti izolata na antimikotike, što obično traje još nekoliko dana ${ }^{[9,10]}$. Tako prosječno vrijeme porasta kandide $\mathrm{u}$ hemokulturi do praga detekcije senzora automatiziranog sustava iznosi od 19 h za C. tropicalis do 75 h za C. glabrata. Nakon signalizacije „pozitivne“ hemokulture potrebno je još 24-48 h za identifikaciju vrste konvencionalnim metodama, poput automatizirane Vitek 2 YST kartice (bioMérieux, Marcy-l'Étoile, Francuska), klasične biokemijske metode AuxaColorTM 2 (Bio-Rad Laboratories, Marnes-la-Coquette, Francuska) ili metode zasnovane na korištenju kromogenih hranilišta kao što je HiCrome ${ }^{\text {mo }}$ Candida Differential Agar ili CHROMagar $^{\mathrm{TM}}$ Candida (CHROMagar, Springfield, New Jersey, SAD). Nažalost, korištenje klasične dijagnostike iziskuje mnogo vremena što ima za posljedicu odgodu ciljanih terapijskih intervencija s lošim ishodima za bolesnika. Primjena novih molekularnih metoda za identifikaciju najčešćih vrsta kandida iz pozitivnih hemokultura kao što je FilmArray (BioFire Diagnostics, Salt Lake City, SAD) znatno skraćuje postupak naknadne identifikacije na 1-2 $\mathrm{h}$.

\section{Nekultivacijska dijagnostika}

Sve veći broj visoko rizičnih bolesnika i potreba za identifikacijom gljiva do razine vrste, naveo je istraživače na razvoj i primjenu novih metoda za identifikaciju gljiva koje nadilaze klasične fenotipske metode. S obzirom na nedovoljnu osjetljivost i dugo vrijeme inkubacije neophodno za kultivaciju gljiva, razvoj i validacija bržih i osjetljivijih nekultivacijskih postupaka je od velikog značaja kod bolesnika s invazivnom kandidijazom. Neki od nekultivacijskih testova su: testovi koji detektiraju biomarkere tj. antigene komponente staničnog zida gljive (manan i $\beta$-D-glukan), antitijela (protiv manana i protiv hifa), te različiti molekularni testovi (Tablica 1). Primjena nekultivacijskih metoda dijagnostike kod sumnje na kandidemiju dovodi do bržeg prepoznavanja kandidemije i samim time ranije primjene odgovarajuće terapije te smanjenja stope morbiditeta i mortaliteta ${ }^{[11]}$. Ipak, nedostatak ovih novijih brzih metoda je nedovoljna standardizacija kao i validacija.

TABlica 1. NeKUltivaCijSKI DiJAgNOSTIČKI TESTOVI

TABle 1. „Non-Culture” Diagnostics tests

\begin{tabular}{|c|c|c|c|}
\hline Test & Princip & Prednost & Nedostatak \\
\hline \multicolumn{4}{|l|}{ Detekcija antigena } \\
\hline $\begin{array}{l}\text { Platelia Candida Ag } \\
\text { Bio-Rad }\end{array}$ & detekcija manana & $\begin{array}{l}\text { osjetljivost oko } 76 \% \text {, } \\
\text { osjetljivost najviša za C. albicans }\end{array}$ & $\begin{array}{l}\text { slaba osjetljivost za C. krusei i } \\
\text { C. parapsilosis }\end{array}$ \\
\hline $\begin{array}{l}\text { Fungitell test } \\
\text { Associates of Cape Cod }\end{array}$ & $\begin{array}{l}\text { detekcija pan-fungalnog markera } \\
1,3-\beta \text {-D-glukana }\end{array}$ & $\begin{array}{l}\text { osjetljivost } 77-91 \% \text {, } \\
\text { visoka NPV, } \\
\text { veća pouzdanost kod dva } \\
\text { pozitivna nalaza }\end{array}$ & $\begin{array}{l}\text { pozitivan kod kolonizacije, } \\
\text { tehnički zahtjevan, } \\
\text { ne razlikuje vrste gljiva, slaba } \\
\text { osjetliivost za C. parapsilosis, } \\
\text { nedovoljno podataka za } \\
\text { pedijatrijsku populaciju }\end{array}$ \\
\hline \multicolumn{4}{|l|}{ Detekcija protutijela } \\
\hline $\begin{array}{l}\text { Platelia Candida Ab } \\
\text { Bio-Rad }\end{array}$ & $\begin{array}{l}\text { detekcija protutijela protiv } \\
\text { manana }\end{array}$ & $\begin{array}{l}\text { osjetljivost } 59 \% \text {, } \\
\text { u kombinaciji s Ag testom je } \\
83 \%\end{array}$ & vrlo niska PPV \\
\hline $\begin{array}{l}\text { C. albicans IFA IgG } \\
\text { Vircell }\end{array}$ & $\begin{array}{l}\text { detekcija protutijela protiv } \\
\text { roteina hifa }\end{array}$ & osjetljivost 77- $89 \%$ & vrlo niska PPV \\
\hline CAGTA Vircell & & $\begin{array}{l}\text { monotestni format, } \\
\text { osjetljivost } 53-73 \%\end{array}$ & vrlo niska PPV \\
\hline \multicolumn{4}{|l|}{ Molekularne metode } \\
\hline $\begin{array}{l}\text { LightCycler }{ }^{\oplus} \text { SeptiFast MGRADE, } \\
\text { Roche Diagnostics } \\
\text { SepsiTest }{ }^{\mathrm{T}} \text {-UMD, Molzym } \\
\text { Magicplex }{ }^{\mathrm{Tm}} \text { Sepsis Seegene, } \\
\text { VYOO }^{\circledR} \text {, SIRS-Lab }\end{array}$ & PCR & $\begin{array}{l}\text { brzina, } \\
\text { velika osjetljivost, } \\
\text { detekcija čestih i rijetkih vrsta } \\
\text { gljiva, } \\
\text { neovisnost o pozitivnoj HK }\end{array}$ & $\begin{array}{l}\text { visoka cijena, } \\
\text { testovi nisu standardizirani, } \\
\text { primjenu ograničiti na određene } \\
\text { odjele/ dijagnoze }\end{array}$ \\
\hline
\end{tabular}




\begin{tabular}{|c|c|c|c|}
\hline $\begin{array}{l}\text { FilmArray BCID2 Panel, } \\
\text { BioFire Diagnostics } \\
\text { ePlex BCID Panel-FP, GenMark }\end{array}$ & $\begin{array}{l}\text { PCR } \\
\text { detekcija } 6 \text { vrsta kandida te } \\
\text { C. auris } \\
\text { detekcija } 11 \text { vrsta kandida te } \\
\text { C. auris }\end{array}$ & $\begin{array}{l}\text { u kombinaciji s pozitivnom HK } \\
\text { identifikacija unutar par sati }\end{array}$ & $\begin{array}{l}\text { visoka cijena, } \\
\text { primjenu ograničiti na određene } \\
\text { odjele/ dijagnoze, } \\
\text { ovisnost o pozitivnoj HK }\end{array}$ \\
\hline $\begin{array}{l}\text { Traffic Light }{ }^{\oplus} \text { PNA-FISH }^{\oplus} \text {, } \\
\text { AdvanDx }\end{array}$ & $\begin{array}{l}\text { fluorescentna in situ hibridizacija } \\
\text { (FISH) }\end{array}$ & $\begin{array}{l}\text { brzina ( } 30-90 \mathrm{~min}) \text {, } \\
\text { identifikacija pet najčešćih vrsta }\end{array}$ & ovisnost o pozitivnoj $\mathrm{HK}$ \\
\hline $\begin{array}{l}\text { T2Candida }{ }^{\oplus} \text { test, } \\
\text { T2Biosystems }\end{array}$ & $\begin{array}{l}\text { kombinacija PCR s T2 } \\
\text { magnetskom rezonancijom } \\
\text { (T2MR) }\end{array}$ & $\begin{array}{l}\text { brzina, } \\
\text { identifikacija pet najčešćih vrsta } \\
\text { kandida, velika osjetljivost } \\
\text { i specifičnost }\end{array}$ & $\begin{array}{l}\text { visoka cijena, } \\
\text { nije registriran u RH }\end{array}$ \\
\hline \multicolumn{4}{|l|}{ Masena spektrometrija } \\
\hline $\begin{array}{l}\text { VITEK }{ }^{\circledast} \text { MS, bioMérieux } \\
\text { MALDI Biotyper }{ }^{\circledast} \\
\text { Bruker Daltonik GmbH }\end{array}$ & $\begin{array}{l}\text { mjerenje signala ioniziranih } \\
\text { proteina ovisno o masi i naboju }\end{array}$ & $\begin{array}{l}\text { brzina ( } 10-30 \mathrm{~min}) \text {, } \\
\text { ušteda radne snage }\end{array}$ & $\begin{array}{l}\text { ovisnost o pozitivnoj HK, } \\
\text { ograničena baza podataka, } \\
\text { visoka cijena uređaja }\end{array}$ \\
\hline
\end{tabular}

Kratice: $H K=$ hemokultura; $N P V=$ negativna prediktivna vrijednost; $P C R=$ lančana reakcija polimeraze; PPV=pozitivna prediktivna vrijednost

\section{Detekcija antigena}

Trenutno su dostupne dvije vrste testova zasnovanih na detekciji antigena. Manan je glavna komponenta staničnog zida kandide koji čini do $7 \%$ ukupne težine suhih stanica i oslobađa se u cirkulaciju tijekom infekcije. Platelia Candida Ag EIA (engl. enzyme immune assay) (Bio-Rad, Marnes-la-Coquette, Francuska) test otkriva prisutnost cirkulirajućeg manana $u$ uzorcima krvi (seruma). Proizvođač deklarira osjetljivost testa od $76 \%$ te specifičnost od $99 \%$. Nekoliko retrospektivnih i prospektivnih studija koje su procjenjivale pouzdanost testa $\mathrm{u}$ dijagnostici invazivne kandidijaze u hematoloških bolesnika i bolesnika u jedinicama intenzivnog liječenja (JIL) pokazale su znatno nižu osjetljivost (od $41 \%$ do $65 \%$ ), ali visoku specifičnost (od 98\% do $100 \%)^{[12-14]}$. Čini se da osjetljivost testa ovisi o vrsti kandide te je najviša za C. albicans dok je najniža za C. tropicalis. U visoko rizičnih bolesnika test se preporučuje provoditi dva do tri puta tjedno, zbog kratkotrajne prisutnosti manana u krvi tijekom epizode kandidemije, uz istodobnu pojavu antitijela protiv manana.

Druga vrsta testa za detekciju gljivičnih antigena usmjerena je na određivanje prisutnosti $1,3-\beta$-D-glukana (BDG), koji je važna komponenta stanične stijenke većine gljiva. Radi se o kvantitativnom turbodimetrijskom testu, u kojem se kao uzorak također koristi serum. BDG je pan-fungalni marker invazivnih gljivičnih infekcija koji se otpušta u krv tijekom infekcija uzrokovanih kandidom, aspergilusom i drugim plijesnima. Različite su studije pokazale osjetljivost od $77 \%$ do $91 \%$ i specifičnost od $85 \%$ za ispitanike s dokazanom ili vjerojatnom invazivnom gljivičnom infekcijom ${ }^{[11,15-18]}$. Test je tehnički zahtjevan i osjetljiv na kontaminaciju, a njegova prednost je brzina izvođenja
- rezultati su dostupni unutar jednog sata. Testiranje BDG-a u visokorizičnih bolesnika omogućuje dijagnostiku invazivne gljivične infekcije i prije pojave kliničkih simptoma, omogućavajući tako ranu primjenu antimikotika. Preporučuje se ponavljanje testiranja sa svrhom povećanja osjetljivosti, a pouzdanost testa je veća u slučaju dva ili više uzastopno pozitivnih rezultata. Primjena odgovarajuće antifungalne terapije korelira s padom titra BDG-a u serumu kod bolesnika, a test ima izrazito dobru negativnu prediktivnu vrijednost $^{[19]}$. Međutim, lažno pozitivni rezultati mogući su $\mathrm{u}$ hemodijaliziranih bolesnika, kod intravenske primjene imunoglobulina, tijekom liječenja $\beta$-laktamskim antibioticima (amoksicilin s klavulanskom kiselinom), u prisutnosti nekih streptokoknih infekcija kao i u slučaju kolonizacije dišnog i probavnog sustava kvascima ili plijesnima ${ }^{[20]}$. Kolonizirani dišni i probavni sustav kritično oboljelih bolesnika sadrže visoke razine gljivičnog BDG-a, a hipoksija i ishemija dovode do narušavanja integriteta epitela i povećane propusnosti sluznice te translokacije BDG-a u krvotok što znatno otežava interpretaciju dobivenog pozitivnog rezultata. Ipak, na temelju izvrsne negativne prediktivne vrijednosti ovog testa (gotovo $100 \%$ ), izostanak detekcije BDG-a u ponavljanom testiranju može s visokom vjerojatnošću isključiti invazivnu gljivičnu infekciju. Na tržištu postoji više različitih komercijalnih BDG testova od kojih je Fungitell test (Associates of Cape Cod, Falmouth, USA) među češće korištenim. Test je odobren od strane američke Agencije za hranu i lijekove (engl. The Food and Drug Administration, FDA) te posjeduje CE (fran. Conformité Européenne) oznaku za in vitro dijagnostiku za europsko tržište. U multicentričnoj kliničkoj studiji provedenoj na 107 bolesnika s dokazanom kandidijazom Fungitell test je 
pokazao osjetljivost od 77,6 \% kada je granična vrijednosti postavljena na $80 \mathrm{pg} / \mathrm{mL}$ (preporuka proizvođača ${ }^{[16]}$. Potrebno je naglasiti da različiti komercijalni BDG testovi imaju i različite preporučene granične vrijednosti.

\section{Detekcija protutijela}

Dostupno je nekoliko komercijalnih testova zasnovanih na detekciji protutijela koja se stvaraju na gljivične antigene. Imunoenzimski Platelia Candida Antibody test (Bio-Rad, Marnes-la-Coquette, Francuska) otkriva protutijela protiv manana koja se razvijaju kod bolesnika nakon epizode kandidemije i nestanka antigena iz krvi. Istraživanja pokazuju prosječnu osjetljivost testova na antimananska protutijela oko $59 \%$ i specifičnost oko $83 \%{ }^{[21]}$. Međutim, kada se test kombinira s testom za detekciju antigena manana, osjetljivost i specifičnost se poboljšavaju ( $83 \%$, odnosno $86 \%)$, kako u hematoloških, tako i kod bolesnika u jedinici intenzivnog liječenja (JIL). Treba napomenuti da su anti-kandida protutijela često prisutna i kod bolesnika s oštećenim imunološkim sustavom, onih koji su prethodno imali kandidemiju ili imaju jaku kolonizaciju, što čini pozitivnu prediktivnu vrijednost ovog testa vrlo niskom ${ }^{[21]}$.

Neizravni imunofluorescentni test C. albicans IFA IgG (Vircell, Grenada, Španjolska) otkriva protutijela protiv proteina hifa kandide koji se eksprimiraju nakon invazivne infekcije tkiva te stvaranja biofilma. Ukupna osjetljivost i specifičnost testa varira od 77 $\%$ do $89 \%$, odnosno $91 \%$ do $100 \%$, a osjetljivost je slabija za C. tropicalis ${ }^{[10,21]}$. Indirektnim kemiluminiscentnim testom Invasive candidiasis VirClia (engl. CAGTA, C. albicans germ tube antibodies) istog proizvođača također se mogu detektirati IgG protutijela na hife C. albicans (Vircell, Grenada, Španjolska). Prednost ovog testa je monotestni format kojim se može brzo testirati pojedinačni uzorak seruma automatiziranom metodom bez potrebe sakupljanja većeg broja uzoraka. Proizvođač navodi da se ovim testom može razlikovati kolonizacija od infekcije te da test ima visoku negativnu prediktivnu vrijednost. Međutim, nije poznato koliko dugo nakon infekcije protutijela ostaju prisutna tj. ukazuje li njihova prisutnost na akutnu ili možda na prošlu infekciju. Stoga je potrebno više studija kako bi se potvrdila pouzdanost ovog i sličnih testova za detekciju protutijela u dijagnostici invazivne kandidijaze.

Kako niti jedan od navedenih nekultivacijskih testova nije samodostatan, preporuke brojnih studija su korištenje kombinacije različitih testova sa svrhom povećanja njihove pouzdanosti ${ }^{[22]}$. Primjerice, pozitivni rezultati CAGTA testa i $\beta$-D-glukana u jednom uzorku krvi ili prisutnost $\beta$-D-glukana u dva uzastopna uzorka krvi čini razliku između invazivne kandidijaze i kolonizacije u visoko rizičnih bolesnika. Kombinacija CAGTA i $\beta$-D-glukana ili CAGTA i antigena manana ima vrlo visoku negativnu prediktivnu vrijednost te se može koristiti za pomoć pri odlučivanju o prekidu nepotrebne empirijske terapije kod bolesnika sa sumnjom na kandidemiju. Višekratno istovremeno određivanje prisutnosti antigena $\mathrm{i}$ protutijela $\mathrm{u}$ visoko rizičnih bolesnika bi povećalo vjerojatnost pravovremene dijagnoze. Negativan nalaz prisutnosti antigena i protutijela u serumu po prijemu bolesnika (prije početka infekcije) te serokonverzija ili porast titra protutijela kasnije, po pojavi simptoma, ukazali bi na vjerojatnost umnožavanja gljive i prelazak iz kolonizacije u infekciju.

\section{Molekularne metode}

Lančana reakcija polimeraze (engl. Polymerase Chain Reaction, PCR) omogućava selektivnu amplifikaciju određene sekvence deoksiribonukleinske kiseline (DNK) generirajući milijune kopija sekvence unutar par sati. Prednost molekularnih metoda u odnosu na klasičnu metodu kultivacije je brzina i velika osjetljivost. Dok primjena početnica specifičnih za vrstu omogućava detekciju određene vrste gljive, primjena početnica širokog spektra (engl. pan-fungal primers) omogućava detekciju i čestih i rijetkih vrsta gljiva. Dostupan je veliki broj komercijalnih, kao i in-house PCR testova za otkrivanje nukleinskih kiselina kandida u različitim biološkim uzorcima. Osim toga, razvijen je i veći broj komercijalnih multipleks PCR-a testova usmjerenih na različite bakterijske, virusne i gljivične uzročnike (uključujući različite vrste kandida). Istovremena identifikacija velikog broja uzročnika u jednoj reakciji štedi vrijeme i rad laboratorijskog osoblja. Riječ je o sindromskim test-panelima dizajniranim za otkrivanje određenog spektra specifičnih patogena. Ovi se testovi izvode izravno iz kliničkih uzoraka (npr. krv, likvor, BAL), a neki od njih su: LightCycler ${ }^{\circledR}$ SeptiFast (Roche Diagnostics GmbH, Manheim, Njemačka), SepsiTest ${ }^{\mathrm{TM}}$ (Molzym Molecular Diagnostics, Bremen, Njemačka), Magicplex ${ }^{\mathrm{TM}}$ Sepsis test (Seegene, Seul, Južna Koreja), VYOO ${ }^{\circledR}$ (SIRS-Lab, Jena, Njemačka), BioFire FilmArray (bioMérieux, Marcy-l'Étoile, Francuska). S obzirom na relativno visoku cijenu multipleks panel testova, njihova bi primjena trebala biti ograničena na određene bolničke odjele ili određene dijagnoze, npr. sumnja na meningitis, gdje je za kliničko odlučivanje potreban brz rezultat dijagnostičke pretrage $^{[23]}$.

Unatoč visokoj osjetljivosti i specifičnosti PCR testova za dijagnozu invazivne kandidijaze, metaanaliza 
većeg broja studija je pokazala da testovi temeljeni na PCR-u imaju nekih nedostataka ${ }^{[10,11]}$. S jedne strane, oni još uvijek nisu metodološki standardizirani za rutinsku kliničku praksu, dok s druge strane i ovi testovi mogu dati lažno negativan rezultat radi malog broja gljivičnih stanica u krvi, kao i poteškoća tijekom pripreme samog uzorka (npr. neučinkovita izolacija nukleinskih kiselina). Isto tako, mogući su i lažno pozitivni rezultati zbog sličnosti između gljivične i ljudske DNK kao i egzogenog onečišćenja (kontaminacija uzorka s gljivičnom DNK iz okoliša, predmeta, kože, zraka itd.).

Molekularni se testovi mogu kombinirati s klasičnom dijagnostikom skraćujući znatno vrijeme potrebno za identifikaciju uzročnika. Na tržištu je nekoliko molekularnih testova za detekciju kandida izravno iz pozitivne hemokulture. FilmArray BCID2 Panel (BioFire Diagnostics, Salt Lake City, SAD) uz brojne bakterije i gene rezistencije može detektirati pet najčešćih vrsta kandida te C. auris, dok ePlex BCID Panel-FP (GenMark, Carlsbad, SAD) unutar par sati detektira 11 vrsta kandida, a također i C. auris i nekoliko drugih kvasaca.

Traffic Light $^{\oplus}$ PNA-FISH $^{\oplus}$ (AdvanDx, Woburn, SAD) je metoda fluorescentne in situ hibridizacije (FISH) odobrena od FDA za dijagnostiku invazivne kandidijaze. Upotrebom peptidonukleotidnih (PNA) sonda moguće je identificirati različite klinički značajne vrste kandida (C. albicans, C. glabrata, C. parapsilosis, C. tropicalis i C. krusei) izravno iz bočica pozitivne hemokulture. Na ovaj se način vrijeme identifikacije uzročnika iz pozitivne hemokulture skraćuje na 30-90 min. Jedan od glavnih nedostataka PNA-FISH testa jest što pretraga ipak ovisi o pozitivnoj hemokulturi (koja je u 50 \% slučajeva negativna što znatno umanjuje osjetljivost testa) ${ }^{[1]}$.

Primjenom novih molekularnih metoda pokušao se riješiti problem ovisnosti o pozitivnoj hemokulturi izravnom identifikacijom kvasaca iz krvi. Riječ je o nanodijagnostičkom T2Candida ${ }^{\varpi}$ testu (T2Biosystems, Lexington, Massachusetts, SAD) odobrenom od strane FDA za dijagnozu invazivne kandidijaze ${ }^{[24,25]}$. T2Candida ${ }^{\oplus}$ je minijaturizirana molekularna metoda koja kombinira PCR s T2 magnetskom rezonancijom (T2MR). Ovaj test omogućava identifikaciju pet klinički najznačajnijih vrsta (C. albicans, C. glabrata, $C$. parapsilosis, C. tropicalis i C. krusei) već u koncentracijama od 1 do $3 \mathrm{CFU} / \mathrm{mL}$ iz uzoraka pune krvi u roku od 3-4 sata ${ }^{[25]}$. Studijom na 1500 kliničkih bolesničkih uzoraka te 300 uzoraka krvi u koje su inokulirane navedene vrste kandida u različitim koncentracijama, dobivena je osjetljivost T2MR testa od 91,1\% i specifičnost od $99,4 \%{ }^{[26]}$. Treba napomenuti da se ovim testom detektira samo pet najčešćih vrsta kandida, dok se propuštaju ostale, rjeđe izolirane vrste među kojim i višestruko rezistentna $C$. auris. Iako brz i osjetljiv, T2MR test je iznimno skup i potrebno je još kliničkih studija za procjenu njegovog kliničkog značaja ${ }^{[27]}$. U nedavno objavljenom preglednom radu o primjeni T2MR testa u kritično oboljelih bolesnika koji imaju rizik za razvoj invazivne kandidijaze Honore i sur. naglašavaju da se najveća dijagnostička točnost ovog testa postiže kombiniranjem rezultata s rezultatima dobivenim klasičnom metodom kultivacije ili detekcijom antigena manana ${ }^{[28]}$. Upotreba T2MR testa u visoko rizičnih bolesnika ima potencijal za bržu identifikaciju uzročnika, raniju primjenu ciljane terapije, raniju deeskalaciju empirijske terapije i kraću hospitalizaciju bolesnika u JIL-u u odnosu na klasičnu dijagnostiku zasnovanu samo na kultivaciji. $U$ navedenom se istraživanju ističe da T2MR može poslužiti u dijagnostici kandidijaze unutarnjih organa, osobito u slučajevima s negativnim rezultatom hemokulture, kao i kod nemogućnosti dobivanje kliničkih uzoraka invazivnim metodama ${ }^{[28]}$. T2MR test ima visoku negativnu prediktivnu vrijednost, no njegova pozitivna prediktivna vrijednost, kao i kod drugih nekultivacijskih testova, je varijabilna i ovisi o prevalenciji invazivne kandidijaze u testiranoj populaciji.

\section{Masena spektrometrija i proteomika}

MALDI-TOF MS (engl. Matrix Assisted Laser Desorption/Ionization Time of Flight Mass Spectrometry) metoda je masene spektrometrije temeljena na mjerenju signala, ovisno o masi i naboju analiziranih molekula, a koja omogućava identifikaciju širokog spektra patogenih mikroorganizama (uključujući i različite vrste kandida). VITEK ${ }^{\oplus}$ MS (bioMérieux, Marcy-l'Étoile, Francuska) i MALDI Biotyper ${ }^{\circledR}$ (Bruker Daltonik GmbH, Bremen, Njemačka) su MALDI-TOF MS instrumenti koje je FDA odobrila za dijagnostiku invazivne kandidijaze. Primjena ove metode omogućava identifikaciju kvasca iz pozitivne bočice hemokulture za 10-30 min. U brojnim laboratorijima se, radi nižih troškova reagensa i uštede radne snage, konvencionalne tradicionalne metode zamjenjuju ovom tehnologijom koja je nadopunjena i detekcijom rezistencije na antifungalne lijekove. Međutim, iako točna i brza, MALDI-TOF MS metoda ima i neke nedostatke; ovisnost o pozitivnoj hemokulturi, ograničena baza podataka i visoka cijena uređaja ${ }^{[11]}$.

Tijekom proteklog desetljeća novije proteomske tehnike, kao što je serološka proteomska analiza (engl. serological proteome analysis, SERPA), koriste se za identifikaciju imunoreaktivnih proteina kao potencijalnih biomarkera u serološkoj dijagnostici različitih zaraznih bolesti ${ }^{[29]}$. Proteini hifa C. albicans koji 
se izlučuju prilikom invazije tkiva domaćina ulaze u interakciju s domaćinom i njegovim imunološkim odgovorom, rezultirajući stvaranjem različitih protutijela. Primjenom imunoproteomike Vaz i sur. su najprije analizirali hifalni sekretom (secernirani proteom) C. albicans, a potom ispitali serološki odgovor na njega kod bolesnika s invazivnom kandidijazom $s$ ciljem identifikacije potencijalnih dijagnostičkih biomarkera $^{[30]}$. U navedenom je istraživanju identificiran 301 secernirani hifalni protein, a za sedam proteina je ustanovljena izrazita imunogenost. Uočeni su različiti serološki obrasci reaktivnosti IgG protutijela na tih sedam proteina u pojedinih skupina; u 12 bolesnika $s$ invazivnom kandidijazom, 11 bolesnika s kateter-povezanom invazivnom kandidijazom te u 11 bolesnika kontrolne skupine. Istraživači smatraju da bi se različiti obrasci seroreaktivnosti na pojedine proteine mogli iskoristiti za razvoj novih komercijalnih dijagnostičkih testova, s tim da bi prethodno trebalo klinički validirati biomarkere u većoj skupini bolesnika.

\section{Ispitivanje osjetljivosti}

Nakon postavljanja dijagnoze invazivne kadidijaze slijedi testiranje osjetljivosti izolata na antimikotike. Lijekovi koji se koriste za liječenje invazivne kandidijaze mogu se podijeliti u tri skupine: azoli, ehinokandini i polieni. Odabir lijeka ovisi o bolesniku i njegovom komorbiditetu, o vrsti kandide, mjestu infekcije i sigurnosnom profilu lijeka.

Azoli su antifungalni lijekovi širokog spektra djelovanja. Djeluju protiv većine vrsta kandida. Općenito se dobro podnose, imaju predvidljive interakcije s drugim lijekova i prednost im je što se mogu primjenjivati intravenski ili oralno. Azoli inhibiraju lanosterol 14 a-demetilazu, ključni enzim u stvaranju ergosterola, koji je glavni sastojak stanične membrane gljiva. Flukonazol je do nedavno bio lijek izbora za liječenje kandidemije, a sada se u većini slučajeva primjenjuje kao lijek drugog izbora ${ }^{[31]}$. C. krusei je u pravilu rezistentna na flukonazol, a C. glabrata je manje osjetljiva nego C. albicans $^{[31]}$. Treba napomenuti da je terapija azolima poželjna u specifičnim kliničkim situacijama, poput endoftalmitisa, meningitisa i kandidijaze mokraćnog sustava, u kojima ehinokandini ne dosežu dovoljne koncentracije, jer ne prolaze krvno-moždanu barijeru i ne izlučuju se u urin.

Ehinokandini su novija klasa antifungalnih lijekova koji inhibiraju sintezu 1,3 beta-glukana, enzima potrebnog za stvaranje stanične stijenke gljiva. Imaju odlično fungicidno djelovanje na većinu vrsta kandida. Najvažniji predstavnici su kaspofungin, anidulafungin i mikafungin. Ehinokandini su sigurni i učinkoviti lijekovi s ograničenom interakcijom s drugim lijekovi- ma, međutim može ih se primijeniti isključivo intravenski. $\mathrm{Za} C$. parapsilosis minimalne inhibitorne koncentracije ehinokandina su više od onih za druge vrste kandida.

Polieni, pritom misleći na amfotericin B, se na gljivičnoj membrani vežu za ergosterol i imaju široko djelovanje protiv svih Candida spp. ali ne i protiv C. lusitaniae, koja je često rezistentna ${ }^{[32]}$. Poželjni su lipidni pripravci amfotericina B zbog njihove djelotvornosti, niže učestalosti nuspojava i smanjenog rizika od nefrotoksičnosti u usporedbi s amfotericin B deoksiholatom.

Prema ažuriranim smjernicama ESCMID-a, flukonazol se više ne smatra lijekom prvog izbora za invazivnu kandidijazu, nego se prednost daje ehinokandinima $^{[33]}$. I smjernice Američkog infektološkog društva (engl. IDSA, Infectious Diseases Society of America) također daju prednost ehinokandinima u empirijskoj terapiji gljivičnih infekcija ${ }^{[34]}$. Brojni su razlozi za ovu preporuku - ehinokandini imaju bolje fungicidno djelovanje nego flukonazol, imaju širi spektar djelovanja, izvrstan sigurnosni profil te malo interakcija s drugim lijekovima. Međutim, unatoč svim dokazima o superiornosti ehinokandina i pojavi rezistencije na flukonazol, posebno među non-albicans vrstama kandida, flukonazol se i dalje široko koristi u kliničkoj praksi za liječenje kandidijaze.

Kao što je navedeno u smjernicama IDSA iz 2016 god., flukonazol ostaje prihvatljiva alternativa za bolesnike koji nisu kritično bolesni te predstavlja lijek izbora za deeskalaciju terapije. Izolati rezistentni na ehinokandine, posebice C. glabrata, često su otporni i na flukonazol te se povezuju s lošim kliničkim isho$\operatorname{dom}^{[35]}$.

\section{Zaključak}

Invazivna kandidijaza postaje sve veći zdravstveni problem zbog rastućeg broja visoko rizičnih bolesnika, a brza dijagnostika gljivične infekcije te posljedično rana primjena odgovarajućih antimikotika je od presudne važnosti. S druge strane, nepotrebna i prekomjerna empirijska primjena lijekova bolesnika izlaže nepotrebnim nuspojavama i dovodi do razvoja rezistencije gljiva na antimikotike. S obzirom na slabu osjetljivost klasične dijagnostičke metode, kultivacije uzročnika, tijekom posljednjih desetljeća razvijene su osjetljivije nekultivacijske tehnike kao što su detekcija biomarkera te molekularne i proteomičke metode. Zbog vrlo visoke negativne prediktivne vrijednosti, negativan nalaz BDG ili PCR testa kod bolesnika s rizikom od razvoja kandidijemije mogao bi biti koristan za odluku o prekidu antifungalne terapije. Premda se detekcijom biomarkera ne postavlja konačna dijagnozu 
već ukazuje na vjerojatnost gljivične infekcije, kombinacija pojedinih nekultivacijskih testova može poboljšati njihovu pouzdanost. Iako nekultivacijske dijagnostičke metode mogu znatno ubrzati i nadopuniti dijagnostiku invazivne kadidijaze još uvijek nije provedeno dovoljno kliničkih istraživanja o njihovoj primjeni. Bez obzira koliko osjetljiv ili specifičan test bio, kliničari moraju prihvatiti određenu razinu nesigurnosti prilikom tumačenja njegovih rezultata. Naime, svaki je test koristan samo u kontekstu svih ostalih kliničkih, epidemioloških i drugih laboratorijskih podataka o bolesniku te ga u skladu s time treba i tumačiti.

\section{LITERATURA:}

${ }^{[1]}$ Pappas P, Lionakis M, Arendrup M, Ostrosky-Zeichner L, Kullberg BJ. Invasive candidiasis. Nat Rev Dis Primers. 2018; 4:18026.

${ }^{[2]}$ Statistics of invasive candidiasis [Internet]. CDC. 2020 [cited 6 May 2021]. Available from: https://www.cdc.gov/fungal/diseases/candidiasis/invasive/statistics.html.

${ }^{[3]}$ Healthcare-associated infections: surgical site infections - Annual Epidemiological Report for 2016 [Internet]. ECDC. 2016 [cited 6 May 2021]. Available from: https://www.ecdc.europa. eu/en/publications-data/healthcare-associated-infections-surgical-site-infections-annual-0

${ }^{[4]}$ Clancy CJ, Nguyen MH. Finding the "Missing 50\%" of Invasive Candidiasis: How Nonculture Diagnostics Will Improve Understanding of Disease Spectrum and Transform Patient Care. Clin Infect Dis. 2013;56(9):1284-92.

${ }^{[5]}$ Pfaller M, Diekema D, Gibbs D, et al. Results from the ARTEMIS DISK Global Antifungal Surveillance Study, 1997 to 2007: 10.5-Year Analysis of Susceptibilities of Noncandidal Yeast Species to Fluconazole and Voriconazole Determined by CLSI Standardized Disk Diffusion Testing. J Clin Microbiol. 2008;47(1):117-23.

${ }^{[6]}$ Ricotta EE, Lai YL, Babiker A, et al. Invasive Candidiasis Species Distribution and Trends, United States, 2009-2017. J Infect Dis 2021;223:1295-302.

[7] Calandra T, Roberts J, Antonelli M, Bassetti M, Vincent J. Diagnosis and management of invasive candidiasis in the ICU: an updated approach to an old enemy. Crit Care. 2016; 20(1):125.

${ }^{[8]}$ Nawrot U, Kowalska-Krochmal B, Sulik-Tyszka B, et al. Evaluation of blood culture media for the detection of fungi. Eur J Clin Microbiol Infect Dis. 2014;34(1):161-7.

${ }^{[9]}$ Pfeiffer C, Samsa G, Schell W, Reller L, Perfect J, Alexander B. Quantitation of Candida CFU in Initial Positive Blood Cultures. J Clin Microbiol. 2011;49(8):2879-83.

${ }^{[10]}$ Freeman Weiss Z, Leon A, Koo S. The Evolving Landscape of Fungal Diagnostics, Current and Emerging Microbiological Approaches. J Fungi (Basel). 2021;7(2):127.

${ }^{[11]}$ Pitarch A, Nombela C, Gil C. Diagnosis of Invasive Candidiasis: From Gold Standard Methods to Promising Leading-edge Technologies. Curr Top Med Chem. 2018; 18(16):1375-92.

${ }^{[12]}$ Alam FF, Mustafa AS, Khan ZU. Comparative evaluation of $(1,3)$ - $\beta$-D-glucan, mannan and anti-mannan antibodies, and Candida species-specific snPCR in patients with candidemia. BMC Infect Dis. 2007;7:103.
${ }^{[13]}$ Hartl B, Zeller I, Manhart A, Selitsch B, Lass-Flörl C, Willinger B. A Retrospective Assessment of Four Antigen Assays for the Detection of Invasive Candidiasis Among High-Risk Hospitalized Patients. Mycopathologia 2018;183(3):513-9.

${ }^{[14]}$ Li F, Yu X, Ye L, Zhou G, Wang L, Luo Y. Clinical value of $(1,3)-\beta$-D-glucan, mannan, antimannan IgG and IgM antibodies in diagnosis of invasive candidiasis. Med Mycol. 2019; 57(8):976-86.

${ }^{[15]}$ Mokaddas E, Khan Z, Ahmad S, Nampoory M, Burhamah M. Value of (1-3)- $\beta$-D-glucan, Candida mannan and Candida DNA detection in the diagnosis of candidaemia. Clin Microbiol Infect. 2011;17(10):1549-53.

${ }^{[16]}$ Ostrosky-Zeichner L, Alexander B, Kett D, et al. Multicenter Clinical Evaluation of the (1-3)-beta-D-Glucan Assay as an Aid to Diagnosis of Fungal Infections in Humans. Clin Infect Dis. 2005;41(5):654-9.

${ }^{[17]}$ Koo S, Bryar J, Page J, Baden L, Marty F. Diagnostic Performance of the (1-3)- $\beta$-d-Glucan Assay for Invasive Fungal Disease. Clin Infect Dis. 2009;49(11):1650-9.

${ }^{[18]}$ Mokaddas E, Burhamah M, Khan Z, Ahmad S. Levels of (1-3)- $\beta$-D-glucan, Candida mannan and Candida DNA in serum samples of pediatric cancer patients colonized with Candida species. BMC Infect Dis. 2010;10(1):1-6.

${ }^{[19]}$ Prella M, Bille J, Pugnale M, et al. Early diagnosis of invasive candidiasis with mannan antigenemia and antimannan antibodies. Diag Microbiol Infect Dis. 2005;51(2):95-101.

${ }^{[20]}$ Mennink-Kersten MA, Warris A, Verweij PE. $(1,3)-\beta$-d-glucan in patients receiving intravenous amoxicillin-clavulanic acid. N Engl J Med. 2006; 354(26):2834-5.

${ }^{[21]}$ Khan Z, Ahmad S. Invasive candidiasis: A review of nonculture-based laboratory diagnostic methods. Indian J Med Microbiol. 2012;30(3):264-9.

${ }^{[22]}$ Sendid B, Tabouret M, Poirot J, Mathieu D, Fruit J, Poulain D. New Enzyme Immunoassays for Sensitive Detection of Circulating Candida albicans Mannan and Antimannan Antibodies: Useful Combined Test for Diagnosis of Systemic Candidiasis. J Clin Microbiol. 1999; 37(5):1510-7.

${ }^{[23]}$ Kidd S, Chen S, Meyer W, Halliday C. A New Age in Molecular Diagnostics for Invasive Fungal Disease: Are We Ready? Front Microbiol. 2020;10:2903.

${ }^{[24]}$ FDA allows marketing of the first test to identify five yeast pathogens directly from a blood sample [Internet]. 2014 [cited 6 May 2021]. Available from: http://www.fda.gov/NewsEvents/ Newsroom/PressAnnouncements/ucm415728.htlm.

${ }^{[25]}$ Brooks M. FDA Clears Rapid Blood Test for Sepsis-Causing Pathogens [Internet]. Medscape. 2014 [cited 6 May 2021]. Available from: https://www.medscape.com/viewarticle/832185.

${ }^{[26]}$ Tang DL, Chen X, Zhu CG, Li ZW, Xia Y, Guo XG. Pooled analysis of T2 Candida for rapid diagnosis of candidiasis. BMC Infect Dis. 2019;19(1):798.

${ }^{[27]}$ Walker B, Powers-Fletcher MV, Schmidt RL, Hanson KE. Cost-Effectiveness Analysis of Multiplex PCR with Magnetic Resonance Detection versus Empiric or Blood Culture-Directed Therapy for Management of Suspected Candidemia. J Clin Microbiol. 2016;54(3):718-26.

${ }^{[28]}$ Honore PM, Redant S, Preseau T, et al. T2MR can be used as a non-culture-based test together with biomarkers to improve detection of Candida in the bloodstream and reduce time delay in treating invasive candidiasis. Expert Rev Anti Infect Ther. 2021:1-3. 
${ }^{[29]}$ Fulton KM, Martin SS, Wolfraim L, Twine SM. Methods and applications of serological proteome analysis. Methods Mol Biol. 2013;1061:97-112.

${ }^{[30]}$ Vaz C, Pitarch A, Gómez-Molero E, et al. Mass Spectrometry-Based Proteomic and Immunoproteomic Analyses of the Candida albicans Hyphal Secretome Reveal Diagnostic Biomarker Candidates for Invasive Candidiasis. J Fungi (Basel). 2021;7(7):501.

${ }^{[31]}$ Berkow EL, Lockhart SR. Fluconazole resistance in Candida species: a current perspective. Infect Drug Resist. 2017;10:237-45.

${ }^{[32]}$ Hawkins JL, Baddour LM. Candida lusitaniae Infections in the Era of Fluconazole Availability. Clin Infect Dis. 2003;36(2):14-8.
${ }^{[33]}$ Cornely OA, Bassetti M, Calandra T, et al. ESCMID ${ }^{\star}$ guideline for the diagnosis and management of Candida diseases 2012: non-neutropenic adult patients. Clin Microbiol Infect. 2012; 18:19-37.

[34] Pappas PG, Kauffman CA, Andes DR, et al. Clinical Practice Guideline for the Management of Candidiasis: 2016 Update by the Infectious Diseases Society of America. Clin Infect Dis. 2016;62(4):e1-50.

${ }^{[35]}$ Bassetti M, Righi E, Montravers P, Cornely OA. What has changed in the treatment of invasive candidiasis? A look at the past 10 years and ahead. J Antimicrob Chemoth. 2018;73(suppl_1), i14-i25. 